\title{
Preparation and Photocatalytic Characterization of Modified TiO2/Nd/rice Husk Ash Nanomaterial for Rifampicin Removal in Aqueous Solution
}

Thuy Dang Thi Ngoc ( $\nabla$ dangngocthuy@gmail.com )

HUMG: Hanoi University of Mining and Geology

Ha Nguyen Thi

Vietnam National University University of Science

Anh Ngo Van

Vietnam National University

Sen Nguyen Thi

Institute of natural resources and environment science

Dung Nguyen Duc

Hanoi University of Mining and Geology

Nam Nguyen Hoang

Hanoi University of Mining and Geology

\section{Research Article}

Keywords: hydrothermal method, Nd, rice husk ash, rifampicin, TiO2 nanomaterial, photocatalyst

Posted Date: July 6th, 2021

DOI: https://doi.org/10.21203/rs.3.rs-581621/v1

License: (c) (i) This work is licensed under a Creative Commons Attribution 4.0 International License.

Read Full License 
1 Preparation and photocatalytic characterization of modified $\mathrm{TiO}_{2} / \mathrm{Nd} /$ rice husk ash nanomaterial for Rifampicin removal in aqueous solution

Thuy Dang Thi Ngoc $^{1^{*}}$, Ha Nguyen Thi $^{2}$, Anh Ngo Van ${ }^{2}$, Sen Nguyen Thi ${ }^{3}$, Dung Nguyen Duc ${ }^{1}$, Nam Nguyen Hoang ${ }^{1}$

${ }^{1}$ Department of Environment, Hanoi University of Mining and Geology, No. 18 Vien street, Bac Tu Liem district, Hanoi, Vietnam

$10{ }^{2}$ Faculty of Environmental Sciences, VNU-University of Science, Vietnam National University, 11 Hanoi - 334 Nguyen Trai, Thanh Xuan, Ha Noi, Vietnam

12

$13{ }^{3}$ Institute of Natural Resources and Environment Science, 7th floor, GIM building, 460 Lane, 14 Khuong Dinh St, Ha Dinh, Thanh Xuan, Ha Noi, Vietnam

15

16

17 *Author for Correspondence:

18 Email: dangngocthuy@gmail.com; Telephone: +84 (0) 969122275

19

20 Keywords: hydrothermal method, $\mathrm{Nd}$, rice husk ash, rifampicin, $\mathrm{TiO}_{2}$ nanomaterial, photocatalyst 21 


\section{Declarations}

24 Ethics approval and consent to participate: Not applicable.

\section{Consent for publication: Not applicable.}

26 Availability of data and materials: The data presented in this study are available on request

27 from the corresponding author. The data are not publicly available due to the information 28 security conditions of the project.

29 Competing interests: The authors declare that they have no competing interests.

30 Funding: Not applicable

31 Authors' contributions: Thuy Dang Thi Ngoc: makes contribution in proposing ideas and

32 designing research; experiment implementation, data collection, data analysis and translation; has

33 contributed to the drafting of the article. Nam Nguyen Hoang: makes an important contribution in

34 proposing ideas and designing research; checks data; data processing; examines the knowledge

35 content of the article; the ratification of the final draft before submitting it to the scientific journal.

36 Ha Nguyen Thi: makes an important contribution in proposing ideas and designing research;

37 checks data; data processing; seriously examines the knowledge content of the article; the

38 ratification of the final draft before submitting it to the scientific journal. Anh Ngo Van: has

39 contributed to the drafting and finalizing of the article, data processing. Sen Nguyen Thi and Dung

40 Nguyen Duc: make contribution in experiment implementation, data collection, data analysis and

41 translation.

\section{Acknowledgements:}

43 The authors would like to sincerely thank the Institute of Biotechnology - Institute of

44 Environmental Technology, Vietnam Academy of Sciences; Center for Environmental Treatment -

45 Military Institute of Science and Technology; Department of Chemistry - Faculty of Basic Sciences

46 - University of Mining - Geology has facilitated and support in the research process. 
Abstract

The neodymium doping of titanium dioxide with content of $\mathrm{Nd}$ varying from 0.01 to $0.8 \%$ was conducted by the sol-gel hydrothermic method. $\mathrm{TiO}_{2} / \mathrm{Nd}$ is then coated on rice husk ash to

52 produce modified $\mathrm{TiO}_{2} / \mathrm{Nd} /$ rice husk ash material using $\mathrm{Nd}$ content of $0.36 \% \mathrm{w} / \mathrm{w}$. The materials' 53 structure characteristic and photocatalytic properties have been analyzed by the XRD, EDX, TEM,

54 SEM, forbidden zone energy (Eg) and specific surface area (BET). $\mathrm{TiO}_{2} / \mathrm{Nd}$ material shows a 55 higher photocatalytic decomposition capacity in comparison to $\mathrm{TiO}_{2}$ and depended on the $\mathrm{Nd}$ 56 content. The Rifampicin removal efficiency of $\mathrm{TiO}_{2} / \mathrm{Nd}$ materials with $\mathrm{Nd}$ contents ranged from 570.36 to $0.80 \%$ had an increase of about $40 \%$ higher than that of $\mathrm{TiO}_{2} / \mathrm{Nd}$ containing $\mathrm{Nd}$ from 0.01 58 to $0.28 \%$. This new photocatalytic $\mathrm{TiO}_{2} / \mathrm{Nd}$ /rice husk ash material is used to decompose 59 Rifampicin. Within 90 minutes under sunlight, the Rifampicin decomposed efficiency of $\mathrm{TiO}_{2} / \mathrm{Nd}$ 60 and $\mathrm{TiO}_{2} / \mathrm{Nd} /$ rice husk ash material reached about 86 and 75\%, respectively. Even lower efficiency 61 was obtained, the latter material was chosen for Rifampicin residue decomposition in the water 62 under sunlight through photocatalytic process because it has some advantages such as smaller 63 amount was needed and easily to be recovered. Rifampicin removal process, $\mathrm{k}$ values were found 64 matching more to zero and first order kinetics. Especially, for powder $\mathrm{TiO}_{2} / \mathrm{Nd}$ and $\mathrm{TiO}_{2} / \mathrm{Nd} / \mathrm{Rice}$ 65 husk ash under solar irradiation the $\mathrm{R}^{2}$ reached about 0.98 .

\section{Introduction}

Rifampicin is an antibiotic with the molecular formula $\mathrm{C}_{43} \mathrm{H}_{58} \mathrm{~N}_{4} \mathrm{O}_{12}$ that works with bacteria of the Mycobacterium strain, especially M. tuberculosis, M. leprae and other Mycobacterium bacteria such as M. bovis, M. avium. The minimum inhibitory concentration for M. tuberculosis bacteria are 0.1 - 2.0 micrograms $/ \mathrm{ml}$. The presence of particular antibiotics 72 especially Rifampicin in water has a significant influence on water treatment by biological 73 methods.

The removal of antibiotic residues has been of great interest to many scientists. Currently, there are many methods of antibiotic residues removal such as absorption, advanced oxidation, 76 biology, photocatalyst etc. Using photocatalyst is one of the techniques that promises to 77 decompose not only persistent organic pollutants (POPs) that are difficult to decompose by 78 biological methods, harmful microorganisms, but also, remove some antibiotics that are difficult 
or impossible to treat by biological methods etc. The characteristic of this type of catalyst is that,

80 under the effect of light, will produce pairs of electrons $\left(\mathrm{e}^{-}\right)$and hole $\left(\mathrm{h}^{+}\right)$, thereby creating 81 compounds with strong oxidation properties and abundant electronic supplies (Choi, 82 Maruthamuthu et al. 2009, Yang, Doudrick et al. 2013, Saucedo-Lucero and Arriaga 2015, 83 Hajizadeh, Amin et al. 2018).

Nano $\mathrm{TiO}_{2}$ has widely used because of its photochemically stable, photocatalytic property, low cost and nontoxic to human and environment. Nano $\mathrm{TiO}_{2}$ that is used as catalyst will not be converted by reactions, therefore, it is required only initial investment for long term use (Wen, $\mathrm{Li}$ et al. 2015, Huang, Lu et al. 2017, Aregu, Asfaw et al. 2018). Therefore, nano-size $\mathrm{TiO}_{2}$ has the economical and technical advantages in inorganic, organic or microbials removal (Aregu, Asfaw et al. 2018). However, due to restricted zone energy of nano-size $\mathrm{TiO}_{2}$ is high $(3,05-3,25 \mathrm{eV})$, only the short wavelength radiation $(<380 \mathrm{~nm})$ could activate the electron from the valence to the conduction bands for photocatalytic activity (Ma, Wang et al. 2014, Wen, Li et al. 2015). Mean whiles, the ultraviolet radiation in the solar radiation reaches the Earth's surface only account about $4 \%$, making the use of this natural source for the purpose of treating environmental problems with

$94 \mathrm{TiO}_{2}$ is limited ( $\mathrm{Li}, \mathrm{Yu}$ et al. 2015, Wen, $\mathrm{Li}$ et al. 2015). Therefore, it is necessary to reduce the 95 band-gap energy of $\mathrm{TiO}_{2}$ so it has photocatalytic activity under the visible light. As a result, many 96 researches have denatured $\mathrm{TiO}_{2}$ materials to narrow down the bending energy $(\mathrm{Eg})$, to enlarge the 97 excitation light from the UV region to the visible area (Ma, Wang et al. 2014, Li, Yu et al. 2015, Wen, Li et al. 2015).

Number of the recent surface modifications or $\mathrm{TiO}_{2}$ structures by various methods have been carried out by introducing metal ions such as $\mathrm{Zn}, \mathrm{Fe}, \mathrm{Cr}, \mathrm{Eu}, \mathrm{Y}, \mathrm{Ag}, \mathrm{Ni}$, etc. and non-metal 101 ions such as $\mathrm{N}, \mathrm{C}, \mathrm{S}, \mathrm{F}, \mathrm{Cl}, \ldots$. These materials have been shown to be effective, enhancing 102 photocatalytic activity in the visible light region (Chen and Mao 2007, Maeda and Domen 2007, 103 Du and Eisenberg 2012, Fukuzumi, Hong et al. 2013, Wanga and Astruc 2014, Li, Yu et al. 2015, 104 Wen, Li et al. 2015).

In addition, due to small and dispersion the $\mathrm{TiO}_{2}$ nanoparticles is difficult to recover for 106 reuse. Therefore, to reduce the cost of products needs to attach $\mathrm{TiO}_{2}$ nanostats to the carrier has a 107 large surface area. These carriers should have the following characteristics: good bonding to the 108 catalyst; no catalytic decomposition effect; has a large surface area; has an affinity for adsorption 
with pollutants such as beeswax, activated carbon, glass, silica gel, polymer materials, zeolite, 110 cotton, cellulose...

111 Husk cover and rice husk ash are agricultural waste, accounting for about one fifth of the

112 World's annual production of rice (about 545 million tons per annum). Globally, there are more 113 than twenty million tons of husk ash released each year (General statistics office 2018). The 114 amount of ash that enters the ecosystem can be damaging to humans and animals, such as silicosis, 115 respiratory failure, and death. Husk ash is used as a good adsorbent for the treatment of many 116 inorganic and organic pollutants (Liu, Guo et al. 2011, Kumar, Sengupta et al. 2015, Zhang, Ding 117 et al. 2015). Therefore, solves a part of agricultural waste, reducing the amount of waste rice husk 118 (Liu, Guo et al. 2011). In addition, husk ash is also used as a carrier for catalytic materials because 119 it has a good mechanical stability, are chemically inert, when used as a carrier will facilitate the 120 separation of catalyst from the solution after reaction. The application of this material is that 121 absorbing nitrogen compounds like Rifampicin (Kumar, Singha et al. 2015).

122 Thus, utilizing rice husk ash and adsorbents of nitrogen - containing organic compounds 123 such as Rifampicin, coupled with photochemical capacities of $\mathrm{TiO}_{2}$ nanoparticles photochemical 124 catalysts for the transfer of Rifampicin to $\mathrm{CO}_{2}, \mathrm{H}_{2} \mathrm{O}, \mathrm{N}_{2}$ (non-toxic). One that solves the problem 125 of minimizing environmental pollution from agricultural waste, on the other hand increases the 126 efficiency of nanomaterials as well as saves on materials and does not require post-processing 127 solutions. It opens up a new way of handling nitrogen compounds as well as can be applied in 128 industry (Cong, Zhang et al. 2007).

\section{Experiment}

\section{Chemicals and equipment}

131 Chemicals used in research include: $\mathrm{TiCl}_{4}, \mathrm{NH}_{4} \mathrm{NO}_{3}, \mathrm{PVA},\left(\mathrm{NH}_{2}\right)_{2} \mathrm{CO}$, Rifampicin (see 132 Figure 1), Methanol, $\mathrm{H}_{2} \mathrm{SO}_{4}, \mathrm{HNO}_{3}, \mathrm{Na}_{2} \mathrm{CO}_{3}, \mathrm{NaOH}, \mathrm{NaH}_{2} \mathrm{PO}_{4}, \mathrm{Na}_{2} \mathrm{HPO}_{4}, \mathrm{NdCl}_{3}$. The chemical 133 compounds have a purity of PA, produced by the Merck, German, distilled water and super 134 distilled water.

Figure 1. The chemical structure of Rifampicin

Husk is taken from the Rice enterprise in Hoai Duc, Ha Noi. The rice husk is washed with 137 distilled water to remove impurities, dried at $105^{\circ} \mathrm{C}$ for $2 \mathrm{hrs}$., then put in furnace at temperatures 138 of $800^{\circ} \mathrm{C}$ for $3 \mathrm{hrs}$. in $\mathrm{N}_{2}$ gas environment to have ash bearing material. The product after furnace 139 is grinded to the size of about $0.1-0.5 \mathrm{~mm}$. 
Water samples: water sample containing Rifampicin is prepared with Rifampicin concentration $20 \mathrm{mg} / \mathrm{L}$. $\mathrm{TiCl}_{4} 0.5 \mathrm{M}$ was prepared from $\mathrm{TiCl}_{4} 3 \mathrm{M}$ by diluted using cold water.

144 Germany; oven Carbolite model AAF-11/7 produced in England. Heating magnetic stirrer IKA by 145 Germany.

146 Preparation of modified $\mathrm{TiO}_{2} / \mathrm{Nd}$ nanomaterial coated in husk ash by the sol-gel hydrothermal 147 method

148 Preparation of modified $\mathrm{TiO}_{2} / \mathrm{Nd}$ nanomaterial by the sol-gel hydrothermal method

$149 \mathrm{TiO}_{2}$ nanomaterial modified $\mathrm{Nd}$ was prepared by the sol-gel hydrothermal method 150 according to Nguyen H.N. et al (2016): Mixing $60 \mathrm{ml} \mathrm{NH}_{4} \mathrm{NO}_{3} 1 \mathrm{M}$ with $450 \mathrm{ml}\left(\mathrm{NH}_{2}\right)_{2} \mathrm{CO} 1 \mathrm{M}+$ $151180 \mathrm{ml} \mathrm{PVA} 1 \mathrm{M}+60 \mathrm{ml} \mathrm{TiCl}_{4}(0,5 \mathrm{M})+$ from 0.1 to $1.0 \mathrm{ml}(1 \mathrm{~g} / \mathrm{L})$; heating to $70^{\circ} \mathrm{C}$, stirring 152 continuously in $24 \mathrm{hrs}$, $1200 \mathrm{rpm}$, then heating up to $90^{\circ} \mathrm{C}$, and stirring for $12 \mathrm{hrs}$. Sol-gel solution 153 obtained was dried at $120^{\circ} \mathrm{C}$ for $12 \mathrm{hrs}$, , then the temperature was increased to $250^{\circ} \mathrm{C}$ for $3 \mathrm{hrs}$. 154 until no more white smoke was released, and black powder was generated. Finally, materials were 155 put in furnace at $600^{\circ} \mathrm{C}$ for $3 \mathrm{hrs}$. with a heating rate of $10^{\circ} \mathrm{C} / \mathrm{min}$. Materials after the furnace were 156 washed 4-5 times with distilled water and super clean water, then dried at $120^{\circ} \mathrm{C}$ for $2 \mathrm{hrs}$ (Nam, 157 Hiep et al. 2016).

158 Table 1. Composition and rate of chemicals prepared nano $\mathrm{TiO}_{2}$ modified $\mathrm{Nd}$ by the sol-gel hydrothermal method

160 Coating $\mathrm{TiO}_{2} / \mathrm{Nd}$ nanomaterial on rice husk ash

161 Husk ash was added into sol-gel solution prepared in section 2.2.(a) to have the 162 concentrations of $\mathrm{TiO}_{2} / \mathrm{Nd}$ in husk ash corresponding $0.1 ; 0.2 ; 0.3 ; 0.4$ and $0.5 \% \mathrm{w} / \mathrm{w}$. The thermal 163 modification process started with well stirring the mixture at $90^{\circ} \mathrm{C}$ for $12 \mathrm{hrs}$. then was followed 164 by similar processes as in the preparation of $\mathrm{Nd}$ modified $\mathrm{TiO}_{2}$ nano-materials in section 165 "Preparation of modified $\mathrm{TiO}_{2} / \mathrm{Nd}$ nanomaterial by the sol-gel hydrothermal method". Rifampicin removal of $\mathrm{TiO}_{2} / \mathrm{Nd}$ nanomaterial and $\mathrm{TiO}_{2} / \mathrm{Nd}$ nanomaterial/husk ash

Put $0.1 \mathrm{~g}$ of powdered $\mathrm{TiO}_{2} / \mathrm{Nd}$ nano-material or $1.0 \mathrm{~g} \mathrm{TiO}_{2} / \mathrm{Nd}$ nanomaterial/husk ash in $200 \mathrm{ml}$ glass cups, add $100 \mathrm{ml}$ of Rifampicin solution at $20 \mathrm{mg} / \mathrm{L}$, stirring the solution at $100 \mathrm{rpm}$. Experiments were conducted under natural light (day and night). The natural light has illumination 
170 intensity of 20.000 Lux. Samples were taken at $0,15,30,45,60,75$ and 90 minutes to analyze

171 residual Rifampicin concentration.

172 Analysis methods

173 The surface area of the husk ash is determined by the BET analysis in $\mathrm{N}_{2}$ environment at

$174196^{\circ} \mathrm{C}$ using NOVA 1200 Quanta chrome-USA. Surface structure of husk ash and $\mathrm{TiO}_{2}$

175 material/husk ash defined by the SEM method (Jeol $5410 \mathrm{LV}$, Japan). Purity of a $\mathrm{TiO}_{2}$ material

176 defined by X-ray diffraction method (XRD), Siemens D5005, Germany. Nano $\mathrm{TiO}_{2}$ particle size

177 determined by TEM, LIBRA120, Germany. The element compositions are analyzed by Energy

178 dispersive analysis of X-rays (EDX), Jeol 6490JED 2300, 2300, Japan.

179 Rifampicin concentration was analyzed by molecular absorption spectrospic method

180 according to Benetton et al. (1998). Calibration curve was prepared using UV-VIS Optizen 181 2120UV, England.

\section{Rifampicin degradation kinetic calculations}

183 The rate of rifampicin degradation and observe the best fit indicating the reaction order 184 were investigated by plotting the remained rifampicin concentration versus time using zero-order, 185 first-order and second-order kinetic models (Vaucher, Paim et al. 2010):

186 Zero-order reaction: $C=C_{0}-k t$

First-order reaction: $C=\ln C_{0}-k t \rightarrow C=C_{0} e^{-k t}$

Second-order reaction: $\frac{1}{C}=\frac{1}{C_{0}}+k t \frac{1}{C}$

Where: $C_{0}$ is the concentration of the reactants under consideration at time zero; $C$ is the concentration after reaction time, $\mathrm{t} ; k$ is the reaction rate constant.

Based on the obtained kinetic graphs, regression coefficients and the kinetics parameters such as apparent order degradation rate constant (k) were identified.

193 Results and discusions

194 Characteristics of powder $\mathrm{TiO}_{2} / \mathrm{Nd}$ modified material

195 Samples of $\mathrm{TiO}_{2} / \mathrm{Nd}$ material obtained after synthesis with different $\mathrm{Nd}$ contents were 196 analyzed the structure, photolysis properties and surface properties using of EDX, XRD, SEM,... 197 measurements.

198 Ermology of nano $\mathrm{TiO}_{2} / \mathrm{Nd}$ modified material 
To analyze the size of the prepared material and their crystal forms, conduct particle size analysis using TEM and XRD. The ermology of the nano $\mathrm{TiO}_{2} / \mathrm{Nd}$ modified materials using the solgel hydrothermical method is shown on Figure 2.

Figure 2. TEM image of $\mathrm{TiO}_{2} / \mathrm{Nd}$ modified nanomaterials with different $\mathrm{Nd}$ content

Figure 2 shows that, with different $\mathrm{Nd}$ content the materials are even in the form of anatase and has a relatively even particle size, at about $<20 \mathrm{~nm}$. Compared to the results of the synthesis of nano materials by the solgel method (Nam, Hiep et al. 2016), the nano $\mathrm{TiO}_{2} / \mathrm{Nd}$ modified materials have the particle sizes more even and smaller than that of non-modified materials. This 208 (2016).

\section{The XRD spectrum of the $\mathrm{TiO}_{2} / \mathrm{Nd}$ modified nanomaterials}

X-ray diffraction (XRD) patterns of the nano TiO2 non-modified materials and the nano $\mathrm{TiO} 2 / \mathrm{Nd}$ modified materials are shown on Figure 3. As can be seen all peaks are sharp and no

212 strange diffraction peaks appeared that prove the prepared $\mathrm{TiO} 2$ materials have a characteristic 213 crystal structure. Diffraction peaks are characteristic at $2 \theta$ values about 25.36 (101), 37.93 (004), 21448.07 (200), 54.03 (105), 55.13 (211) and 62.81 (204) show that the nano materials obtained exist 215 only in the anatase phase. In addition, no characteristic peaks of the rutle and brookite phase 216 appear. materials. Although they are prepared with different $\mathrm{Nd}$ contents, the nano materials obtained are pure, single-phase, without the appearance of diffraction peaks of rare earth ions. Besides, the crystal lattice parameters of materials with different $\mathrm{Nd}$ contents there are differences in lattice constants a and $\mathrm{c}$, in which of nano $\mathrm{TiO}_{2} / \mathrm{Nd}$ modified material found larger sizes than nonmodified materials. This can be explained, since the radius of the $\mathrm{Nd}^{3+}$ ion is larger in size than that of the $\mathrm{Ti}^{4+}$ ion, when the $\mathrm{Nd}^{3+}$ ion replaces the position of the $\mathrm{Ti}^{4+}$ ion in the crystal lattice it will make the crystal larger in size (El-Bahy, Ismail et al. 2009, Nguyễn Văn Hưng, Ngô Sỹ Lương et al. 2012). 
However, the size of the crystal lattice and the density of all 6 materials are almost the same. In addition, these findings are similar to some previous studies where the lattice cell size of

231 the material prepared by the sol-gel hydrothermical method is smaller and the density is larger

232 when modifying by metals (Huang, You et al. 2006, El-Bahy, Ismail et al. 2009, Nguyễn Văn 233 Hưng, Ngô Sỹ Lương et al. 2012).

EDX spectrum of $\mathrm{TiO}_{2} / \mathrm{Nd}$ nanomaterials

235 The percentages of elements contained in nano $\mathrm{TiO}_{2} / \mathrm{Nd}$ materials with different contents 236 of $\mathrm{Nd}$ are in shown in Figure 4.

Figure 4. EDX images of $\mathrm{TiO}_{2} / \mathrm{Nd}$ modified nanomaterials with different $\mathrm{Nd}$ contents Peaks on EDX diagrams specify the presence Ti, $\mathrm{O}$ and $\mathrm{Nd}$ elements in material samples. Peaks of other elements are not appeared. This proves that synthetic $\mathrm{TiO}_{2}$ nanomaterials are highly pure. The results of quantitative analysis of the material's compositions show that Ti content accounts for between 46 and $57 \%$ by weight and from 27 to $31 \%$ by atomic numbers, $\mathrm{O}$ content

242 found in the ranges of $42-54 \%$ and $69-78 \%$ by weight and atomic numbers, respectively. Except $243 \mathrm{Ti}$ and $\mathrm{O}$ peaks, there was peaks of $\mathrm{Nd}$, with a relatively small intensity, accounting for only 0.01 244 to $0.8 \%$ and from 0.01 to $0.14 \%$ by weight and atomic number, respectively.

Nano materials are obtained evenly in single-crystal form and in the form of anatase. In the crystal lattice of $\mathrm{TiO}_{2}$, Ti atoms in some vertices are replaced by $\mathrm{Nd}$ atoms. However, since Ti has valency IV, it will form a bond with the 4 surrounding $\mathrm{O}$ atoms while the $\mathrm{Nd}$ has valency III, so when $\mathrm{Nd}$ is replaced in the position of the $\mathrm{Ti}$ atom, the $\mathrm{Nd}$ atom creates a electric imbalance. In addition, on the surface of $\mathrm{TiO}_{2}$ there are $\mathrm{OH}^{-}$groups that produce from water separation process of oxides. These groups can exist in a free or the surface bond states through hydrogen bonds.

252 absorbed water molecules that can give electrons to form reduced hydroxyl radicals. Therefore,

253 the rate of re-combination between electron-hole pairs is reduced and the photocatalytic activity 254 of $\mathrm{TiO}_{2}$ is enhanced when it is modified by the $\mathrm{Nd}^{3+}$ ion (El-Bahy, Ismail et al. 2009).

255 Eg values of $\mathrm{TiO}_{2} / \mathrm{Nd}$ modified nanomaterial

256 As can be seen in Figure 5, the sample has an $\mathrm{Nd}$ content of $0.16 \%$ for the lowest Eg value. 257 The highest Eg value found at material with an $\mathrm{Nd}$ content of $0.8 \%$, reaching $3.21 \mathrm{eV}$. Thus, when 258 modified by $\mathrm{Nd}$, generally the forbidden zone energy of the material is lower in comparison to 259 non-modified one. That shows the ability to absorb the visible light of these modified materials is 
greatly improved compared to nano $\mathrm{TiO}_{2}$ material. For non-modified $\mathrm{TiO}_{2}$, maximum energy absorption takes place in the ultraviolet radiation region $(\lambda<400 \mathrm{~nm})$ with electron excitation from orbital $2 \mathrm{p}$ of the $\mathrm{O}$ atom the orbital $3 \mathrm{~d}$ of Ti. Therefore, the Eg value of $\mathrm{TiO}_{2} / \mathrm{Nd}$ materials with different $\mathrm{Nd}$ contents significantly decreases to below $2.89 \mathrm{eV}$. As a result, visible light can excite electrons from this intermediate energy level (4f) to the conductive region energy. This is also agreement with the studies on $\mathrm{TO}_{2}$ modified using rare earth elements (Wojcieszak, Kaczmarek et al. 2012, Wojcieszak, Mazur et al. 2014).

Figure 5. Eg spectrum of $\mathrm{TiO}_{2} / \mathrm{Nd}$ modified nanomaterials with different $\mathrm{Nd}$ contents

$\mathrm{TiO}_{2} / \mathrm{Nd}$ nanomaterials coated on rice husk ash

The nano $\mathrm{TiO}_{2} / \mathrm{Nd}$ modified materials coated on rice husk ash are prepared from sol-gel solution similar to those used to make nano $\mathrm{TiO}_{2} / \mathrm{Nd}$ modified materials with a content of $0.36 \%$ $\mathrm{Nd}$. Their photocatalytic activity is compared to nano $\mathrm{TiO}_{2}$ particles. The SEM image of the nano $\mathrm{TiO}_{2} / \mathrm{Nd}$ /rice husk ash material shows that on the surface of the material at the crevices and on the holes, there are nano $\mathrm{TiO}_{2} / \mathrm{Nd}$ particles that are attached and they are fairly evenly distributed throughout the surface of the rice husk ash. The results also indicate that the coatings on the rice husk ash are homogeneity (see Figure 6).

Figure 6. SEM images of rice husk ash (a) and nano $\mathrm{TiO}_{2} / \mathrm{Nd} /$ rice husk ash (b)

Figure 7. XRD (a) and EDX (b) spectrum of nano $\mathrm{TiO}_{2} / \mathrm{Nd} /$ rice husk ash

Figure 7 (a) shows the characterized peaks appeared at the $2 \theta$ position $=25.3^{\circ}$ of $\mathrm{TiO}_{2}$, and $22^{\circ}$ of $\mathrm{SiO}_{2}$ that indicate the presence of $\mathrm{TiO}_{2}$ and $\mathrm{SiO}_{2}$ particles on the surface of nano $\mathrm{TiO}_{2} / \mathrm{Nd}$ /rice husk ash material. Mass and percentage of elements found in nano $\mathrm{TiO}_{2} / \mathrm{Nd} /$ rice husk ash material are presented in Figure 6 (b). The findings show that the material consists mainly of $\mathrm{Si}$, accounting 83.13\%, the $\mathrm{O}$ and $\mathrm{C}$ make up 6.33 And 5.64\%, respectively. However, Ti only

$284 \mathrm{Ca}$ are found to derive from rice husk ash. It shows that nano $\mathrm{TiO}_{2} / \mathrm{Nd}$ coating rice husk ash 285 material by solgel hydrothermal method has been achieved successfully because of high absorption 286 capacity and photocatalytic activity. Using this material makes the continuous operation of the 287 treatment processing without separating the material after treatment. In addition, it not only 288 increases the removal efficiency but also reduces the treatment cost.

\section{Removal effective of rifampicin of $\mathrm{Nd}-\mathrm{TiO}_{2}$ and $\mathrm{Nd}-\mathrm{TiO}_{2} /$ rice husk ash nanomaterials}


The result of photocatalytic decomposition of the rifampicin antibiotic in the presence of $\mathrm{TiO}_{2} / \mathrm{Nd}$ and $\mathrm{TiO}_{2} / \mathrm{Nd} /$ rice husk ash nanomaterials show in Figure 8. The results clearly show that both types of materials obtained have photocatalytic activity. However, the activity of $\mathrm{TiO}_{2} / \mathrm{Nd}$ /rice husk ash material is lower (about $10 \%$ after $90 \mathrm{~min}$ ), compared to the decomposition of 294 rifampicin antibiotics obtained in the case of nano $\mathrm{TiO}_{2} / \mathrm{Nd}$ material. This difference is mainly related to significant differences in the content of nano $\mathrm{TiO}_{2}$, the light absorption ability, the rifampicin's absorption capacity onto the rice husk ash material. Although, both materials are prepared from same size nanoparticles and having the same Eg, the BET surface areas of nano $\mathrm{TiO}_{2} / \mathrm{Nd}$ and $\mathrm{TiO}_{2} / \mathrm{Nd} /$ rice husk ash materials are 58.97 and $107 \mathrm{~m}^{2} / \mathrm{g}$, respectively. The size of the $\mathrm{TiO}_{2} / \mathrm{Nd} /$ rice husk ash is also much larger than the size of the nano $\mathrm{TiO}_{2} / \mathrm{Nd}$ particle. Because of the bulky molecular structure of rifampicin with many functional groups such as $-\mathrm{OH},>\mathrm{NH}$, $>\mathrm{C}=\mathrm{O}$ etc., it can easily make bonds with the metals of the adsorbents. This show more clearly in the experiment results under the dark conditions (see Figure 8). Also, the very fast absorption rate can be seen that maximum absorbability is achieved after 15 minutes.

Under natural light conditions, the photocatalytic efficiency of both materials increases markedly over reaction times. However, the rifampicin decomposition efficiency of nano $\mathrm{TiO}_{2} / \mathrm{Nd}$ particles is higher. This is related to the absorption process as well as the size of the rifampicin molecule. Therefore, the photocatalytic process takes place simultaneously during absorption as below reactions (Thomas, Radhika et al. 2016).

314 and $\mathrm{H}_{2} \mathrm{O}$.

$$
\mathrm{TiO}_{2}+\mathrm{hv} \rightarrow \mathrm{TiO}_{2}\left(\mathrm{~h}^{+}+\mathrm{e}^{-}\right)
$$

$$
\mathrm{TiO}_{2}\left(\mathrm{~h}^{+}\right)+\mathrm{H}_{2} \mathrm{O} \rightarrow * * \mathrm{OH}+\mathrm{H}^{+}+\mathrm{TiO}_{2}
$$

The activated molecules formed will react with the molecules of rifampicin to produce $\mathrm{CO}_{2}$ 
Figure 8. Rifampicin removal efficiency of nano $\mathrm{TiO}_{2} / \mathrm{Nd}$ and $\mathrm{TiO}_{2} / \mathrm{Nd} /$ rice husk ash under different conditions $\left(\mathrm{TiO}_{2} / \mathrm{Nd}-\mathrm{P}\right.$ : nano $\mathrm{TiO}_{2} / \mathrm{Nd}$, natural light; $\mathrm{TiO}_{2} / \mathrm{Nd} / \mathrm{H}-\mathrm{SL}: \mathrm{TiO}_{2} / \mathrm{Nd} / \mathrm{rice}$ husk ash, natural light; $\mathrm{TiO}_{2} / \mathrm{Nd} / \mathrm{H}-\mathrm{D}$ : $\mathrm{TiO}_{2} / \mathrm{Nd} /$ rice husk ash, dark) material, it prevents $\mathrm{OH}^{-}$ion and $\mathrm{O}_{2}$ molecular interact with the material surface, thereby reducing 326 the formation of activated molecules and facilitating the re-combination of e and hole. Therefore, 327 the rifampicin removal efficiency through photochemical reaction is insignificant. As the reaction 328 time is prolonged, the rates of photochemical reaction of both materials markedly increases. The 329 concentration of rifampicin tends to decrease more significantly for nano $\mathrm{TiO}_{2} / \mathrm{Nd}$ materials in 330 comparison to $\mathrm{TiO}_{2} / \mathrm{Nd} /$ rice husk ash. This is probably because the rice husk ash accounts for a 331 large proportion of the $\mathrm{TiO}_{2} / \mathrm{Nd} /$ rice husk ash material (see SEM and EDX).

332 In the later material, nano $\mathrm{TiO}_{2} / \mathrm{Nd}$ particles occupy only a small part of the surface area 333 of the material, therefore, when the rifampicin molecules are absorbed onto the rice husk ash 334 material, the interact between the activated molecules and rifampicin has a lower probability than 335 the nano $\mathrm{TiO}_{2} / \mathrm{Nd}$ material. On the other hand, due to the larger size of the $\mathrm{TiO}_{2} / \mathrm{Nd} /$ rice husk ash 336 material, it prevents light from going deep into the solution, so the decomposition efficiency is 337 lower and the reaction time lasts longer. When the reaction time lasts up to 90 min, the rifampicin 338 decomposition efficiency of $\mathrm{TiO}_{2} / \mathrm{Nd} /$ rice husk ash material reaches about $>75 \%$.

\section{Rifampicin degradation kinetics}

The results of the kinetic calculations relating to the process of removing rifampicin according to the zero, first and second equations were showed in Figure 9.

Summarized results in Table 3 showing that for all 3 kinetics the powder $\mathrm{TiO}_{2} / \mathrm{Nd}$ has the

344 similar to the maximum and minimum $\mathrm{k}$ values, respectively, that were reported in the study of 345 Cizmic et al. (2019) (Cizmic, Ljubas et al. 2019).

Table 3. Kinetics calculations: reaction rate constant and regression coefficients

The Langmuir-Henshilwood kinetics are applied with first-order kinetic similarities as both 348 the absorption process that occurs along with the decomposition reaction take into consideration. 349 Comparison to powder $\mathrm{TiO}_{2} / \mathrm{Nd}$ material, $\mathrm{TiO}_{2} / \mathrm{Nd}$ material coated with rice husk ash in natural 350 light conditions (-SL) has lower $\mathrm{k}$ and $\mathrm{R}^{2}$ values, however these were found better than that of 
$\mathrm{TiO}_{2} / \mathrm{Nd} / \mathrm{H}$ under dark and UV irradiation. For conditions where the use of UV irradiation the

352 value $\mathrm{k}$ is lower than that of natural light may be due to the low intensity of UV radiation and the 353 material has been activated to reduce the forbidden zone energy of material then it can effectively 354 catalyst in the visible area of natural light. In the study of Vaucher et al. (2010), the kinetics of 355 telithromycin photodegradation and oxidative degradation were determined and reported that both photodegradation and oxidative degradation follow first-order reaction kinetics (Vaucher, Paim et al. 2010).

Pseudo-first order kinetic model was commonly used in number of studies to investigate the antibiotic degradation process under the diferent conditions (Zhigang, Wang et al. 2018, Cizmic, Ljubas et al. 2019, Bobirică, Bobirică et al. 2020), photocatalytic degradation of sulfamethazine in aqueous solution using $\mathrm{ZnO}$ was reported. The findings showed that 78 and $95 \%$ of sulfamethazine were degraded after 60 min irradiation, the rate constant $\mathrm{k}$ obtained $2.58 \times 10^{-2}$ and $4.95 \times 10^{-2} \mathrm{~min}^{-1}$ without and with $\mathrm{ZnO}$, respectively.

Figure 9. Concentration of rifampicin remaining versus time according to: zero-order reaction 2015, Kais, Mezenner et al. 2019). In which, the influence of some parameters and kinetic model were investigated. The results showed that the apparent rate constant $\left(\mathrm{k}_{\mathrm{app}}\right)$ and initial rate constant $\left(\mathrm{r}_{0}\right)$ decreased when the initial concentration of rifampicin increased. In sone other studies, the amount of photocatalyst $\left(\mathrm{TiO}_{2}\right)$ and $\mathrm{pH}$ were considered as significant factors affecting the antibiotic degradation process (Radosavljevic, Golubovic et al. 2017, Kais, Mezenner et al. 2019).

\section{Conclusions} sol-gel hydrothermic method using a $\mathrm{TiCl}_{4}$ solution at a temperature of $600^{\circ} \mathrm{C}$. The mateiral properties, photocatalytic reactions of the nano $\mathrm{TiO}_{2} / \mathrm{Nd}$ and $\mathrm{TiO}_{2} / \mathrm{Nd} /$ rice husk ash materials were investigated using modern characteristic techniques. The results showed that $\mathrm{Nd}$ doping affects electronic transiti modification enhe (c) ergy by changing the width of the forbidden zone. Most notably, the $\mathrm{TiO}_{2}$, and depends on the $\mathrm{Nd}$ content. The rifampicin decomposition efficiency of nano $\mathrm{Nd}-\mathrm{TiO}_{2}$ material with $0.36 \% \mathrm{Nd}$ under natural light reaches about $86 \%$ after 90 minutes. The $\mathrm{TiO}_{2} / \mathrm{Nd} /$ rice 
383 husk ash material are successfully prepared when $\mathrm{TiO}_{2} / \mathrm{Nd}$ is coated on rice husk ash by the sol384 gel hydrothermical method, with the content of Ti in the material about $0.19 \%$ (w/w). Although 385 its photocatalytic reaction efficiency to decompose rifampicin is lower than that of nano $\mathrm{Nd}_{-} \mathrm{TiO}_{2}$ 386 materials (more than $75 \%$ after $90 \mathrm{~min}$ ), this material is suggested to use because after the 387 photocatalytic process, the $\mathrm{Nd}-\mathrm{TiO}_{2}$ material still remains on the rice husk ash carrier. Therefore, $388 \mathrm{Nd}-\mathrm{TiO}_{2}$ materials will not release in to solution and not cause secondary environmental pollutants. 389 The $\mathrm{Nd}-\mathrm{TiO}_{2} /$ rice husk ash material can be recovered in a simple method and able to be long use. 390 The kinetics of rifampicin removal follows the zero and first-order reaction kinetics 391 especially for $\mathrm{TiO}_{2} / \mathrm{Nd}-\mathrm{P}$ and $\mathrm{TiO}_{2} / \mathrm{Nd} / \mathrm{H}-\mathrm{SL}$. The $\mathrm{k}$ and $\mathrm{R}^{2}$ values of $\mathrm{TiO}_{2} / \mathrm{Nd} / \mathrm{H}-\mathrm{D}$ and $392 \mathrm{TiO}_{2} / \mathrm{Nd} / \mathrm{H}-\mathrm{UV}$ seem to be similar and remarkable lower than that of powder $\mathrm{TiO}_{2} / \mathrm{Nd}$ and $393 \mathrm{TiO}_{2} / \mathrm{Nd} / \mathrm{H}$ in solar irradiation. 


\section{REFERENCES}

Aregu, M. B., S. L. Asfaw and M. M. Khan (2018). " Identification of two low-cost and locally available filter media (pumice and scoria) for removal of hazardous pollutants from tannery wastewater." Environ Syst Res. 7(1): 10.

Aregu, M. B., S. L. Asfaw and M. M. Khan (2018). "Identification of two low-cost and locally available filter media (pumice and scoria) for removal of hazardous pollutants from tannery wastewater." Environ Syst Res. 7(1): 10.

Bobirică, C., L. Bobirică, M. Râpă, E. Matei, A. M. Predescu and C. Orbeci (2020). "Photocatalytic Degradation of Ampicillin Using PLA/TiO2 Hybrid Nanofibers Coated on Different Types of Fiberglass." Water 12: 176.

Chen, X. and S. S. Mao (2007). "Titanium dioxide nanomaterials: synthesis, properties, modifications, and applications." Chemical Reviews 107(7): 2891-2959.

Choi, J. H., S. Maruthamuthu, H. G. Lee, T. H. Ha and J. H. Bae (2009). "Nitrate removal by electro-bioremediation technology in Korean." soil. J Hazard Mater 11: 1208-1216.

Cizmic, M., D. Ljubas, M. Rožman, D. Ašperger, L. Curkovic and S. Babic (2019). "Photocatalytic Degradation of Azithromycin by Nanostructured TiO2 Film: Kinetics, Degradation Products, and Toxicity." Materials 12: 873.

Cong, Y., J. Zhang, F. Chen, M. Anpo and D. He (2007). "Preparation, Photocatalytic Activity, and Mechanism of Nano-TiO2 Co-Doped with Nitrogen and Iron (III)." Journal of Physical Chemistry 111(28): 10618-10623.

Du, P. and R. Eisenberg (2012). "Catalysts made of earth-abundant elements (Co, Ni, Fe) for water splitting: Recent progress and future challenges." Energy Environ. Sci. 5: 6012-6021. 
427 El-Bahy, Z. M., A. A. Ismail and R. M. Mohamed (2009). "Enhancement of titania by doping rare 428 earth for photodegradation of organic dye (Direct Blue)." Journal of Hazardous Materials 166: $429 \quad 138-143$.

431 Fukuzumi, S., D. Hong and Y. Yamada (2013). "Bioinspired Photocatalytic Water Reduction and 432 Oxidation with Earth-Abundant Metal Catalysts." J. Phys. Chem. Lett. 4(20): 3458-3467.

434 General statistics office (2018). Press release social and economic situation in 9 months of 2017.

437 dimethylhydrazine from air stream using a biofilter packed with compost-scoria-sugarcane bagasse." Atmos Pollut Res. 9(1): 37-46.

440 Huang, C., W. You, L. Dang, Z. Lei, Z. Sun and L. Zhang (2006). "Effect of Nd Doping on 441 Photocatalytic Activity of TiO2 Nanoparticles for Water Decomposition to Hydrogen." Chin. J. 442 Catal. 27: 203-209.

444 Huang, H., H. Lu, Y. Zhan, G. Liu, Q. Feng and H. Huang (2017). "VUV photo-oxidation of 445 gaseous benzene combined with ozone-assisted catalytic oxidation: effect on transition metal 446 catalyst." Appl Surf Sci. 391: 662-667.

448 Kais, H., N. Y. Mezenner, M. Trari and F. Madjene (2019). "Photocatalytic Degradation of 449 Rifampicin: Influencing Parameters and Mechanism." Russian Journal of Physical Chemistry A. 450 93(13): 2834-2841.

452 Kumar, A., B. Sengupta, D. Dasgupta, T. Mandal and S. Datta (2015). "Recovery of value added 453 products from rice husk ash to explore an economic way for recycle and reuse of agricultural 454 waste." Reviews in Environmental Science and Bio/Technology 15(1). 
456 Kumar, A., S. Singha, D. Dasgupta, S. Datta and T. Mandal (2015). "Simultaneous recovery of 457 silica and treatment of rice mill wastewater using rice husk ash: An economic approach." 458 Ecological Engineering 84: 29-37.

460 Li, X., J. Yu, J. Low, Y. Fang, J. Xiaoc and X. Chen (2015). "Engineering heterogeneous 461 semiconductors for solar water splitting." Journal of Materials Chemistry A 3: 2485-2534.

463 Liu, Y., Y. Guo, Y. Zhu, D. An, W. Gao, Z. Wang, Y. Ma and Z. Wang (2011). "A sustainable 464 route for the preparation of activated carbon and silica from rice husk ash." Journal of Hazardous 465 Materials 186(2-3): 1314-1319.

467 Ma, Y., X. Wang, Y. Jia, X. Chen, H. Han and C. Li (2014). "Titanium Dioxide-based 468 Nanomaterials for Photocatalytic Fuel Generations." Chem. Rev, 114: 9987.

Maeda, K. and K. Domen (2007). "New Non-Oxide Photocatalysts Designed for Overall Water

471 Splitting under Visible Light." J. Phys. Chem. C 111: 7851-7861.

473 Nam, N. H., N. H. Hiep, T. T. H. Van and N. T. T. Huong (2016). "Creating nitrogen modified 474 tio2 nano material by urea covered on laterite applying to treat organic compound and bacteria in 475 the outflow of biological treatsystem." Journal of Science of HNUE 61(9): 93-103.

477 Nam, N. H., N. H. Hiep, T. T. H. Van and N. T. T. Huong (2016). "Creating nitrogen modified 478 tio2 nano material by urea covered on laterite applying to treat organic compound and bacteria in 479 the outflow of biological treatsystem." Journal of Science of HNUE 61(9): 93-103.

481 Nguyễn Văn Hưng, Ngô Sỹ Lương, Đặng Thị Thanh Lê and Nguyễn Văn Khanh (2012). "Ảnh 482 hưởng của $\mathrm{Nd} 3$ + đến cấu trúc và hoạt tính quang xúc tác của bột $\mathrm{Nd}-\mathrm{TiO} 2$ kích thước nano điều 483 chế bằng phương pháp thuỷ nhiệt và thuỷ phân." Tạp chí Khoa học và Công nghệ 50(3): 367-374. 
Radosavljevic, K. D., A. V. Golubovic, M. M. Radisic, A. R. Mladenovic, D. Ž. Mijin and S. D. 486 Petrovic (2017). "Amoxicillin photodegradation by nano crystalline TiO2." Chem. Ind. Chem. 487 Eng. Q. 23(2): 187-195.

Safari, G. H., M. Hoseini, M. Seyedsalehi, H. Kamani, J. Jaafari and A. H. Mahvi (2015). "Photocatalytic degradation of tetracycline using nanosized titanium dioxide in aqueous solution." Int. J. Environ. Sci. Technol. 12: 603-616.

Saucedo-Lucero, J. and S. Arriaga (2015). "Study of ZnO-photocatalyst deactivation during continuous degradation of n-hexane vapors." J Photochem Photobiol A 312: 28-33.

Thomas, J., S. Radhika and M. Yoon (2016). "Nd3+-doped TiO2 nanoparticles incorporated with heteropoly phosphotungstic acid: A novel solar photocatalyst for degradation of 4-chlorophenol in water." Journal of Molecular Catalysis A: Chemical 411: 146-156. Telithromycin Determined by HPLC Method " Journal of Chromatographic Science 48: 835-839.

Wanga, C. and D. Astruc (2014). "Nanogold plasmonic photocatalysis for organic synthesis and clean energy conversion." Chem. Soc. Rev. 43(20): 7188-7216.

Wen, J., X. Li, W. Liu, Y. Fang, J. Xie and Y. Xu (2015). "Photocatalysis fundamentals and surface modification of TiO2 nanomaterials." Chinese Journal of Catalysis 36: 2049-2070.

Wojcieszak, D., D. Kaczmarek and J. Domaradzki (2012). "Photocatalytic properties of 510 transparent TiO2 coatings doped with neodymium." Polish Journal of Chemical Technology 14(3): $511 \quad 1-7$.

513 Wojcieszak, D., M. Mazur, M. Kurnatowska, D. Kaczmarek, J. Domaradzki, L. Kepinski and K. 514 Chojnacki (2014). "Influence of Nd-Doping on Photocatalytic Properties of TiO2 Nanoparticles 515 and Thin Film Coatings." International Journal of Photoenergy 2014: 1-10. 
517 Yang, T., K. Doudrick and P. Westerhoff (2013). "Photocatalytic reduction of nitrate using

518 titanium dioxide for regeneration of ion exchange brine." Water Res. 11: 1299-1307.

520 Zhang, H., X. Ding, X. Chen, Y. Ma, Z. Wang and X. Zhao (2015). "A new method of utilizing

521 rice husk: Consecutively preparing d-xylose, organosolv lignin, ethanol and amorphous superfine

522 silica." Journal of Hazardous Materials 291: 65-73.

523

524 Zhigang, Y., J. Wang, T. Jiang, Q. Tang and Y. Cheng (2018). "Photocatalytic degradation of 525 sulfamethazine in aqueous solution using $\mathrm{ZnO}$ with different morphologies." $\underline{\mathrm{R}}$. Soc. Open sci. 5: 526171457. 
Figures

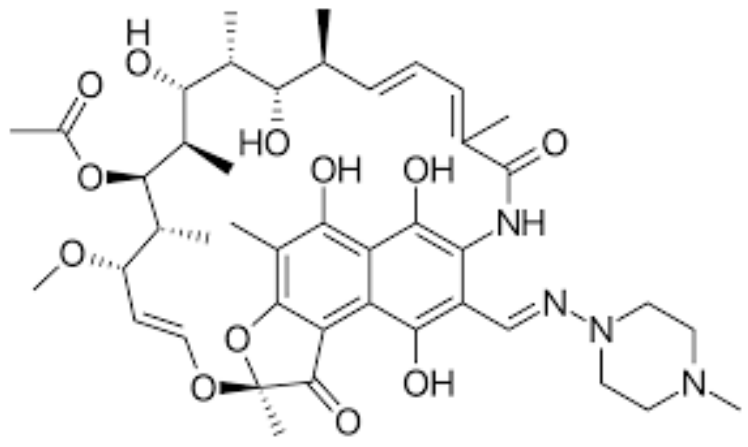

Figure 1. The chemical structure of Rifampicin 

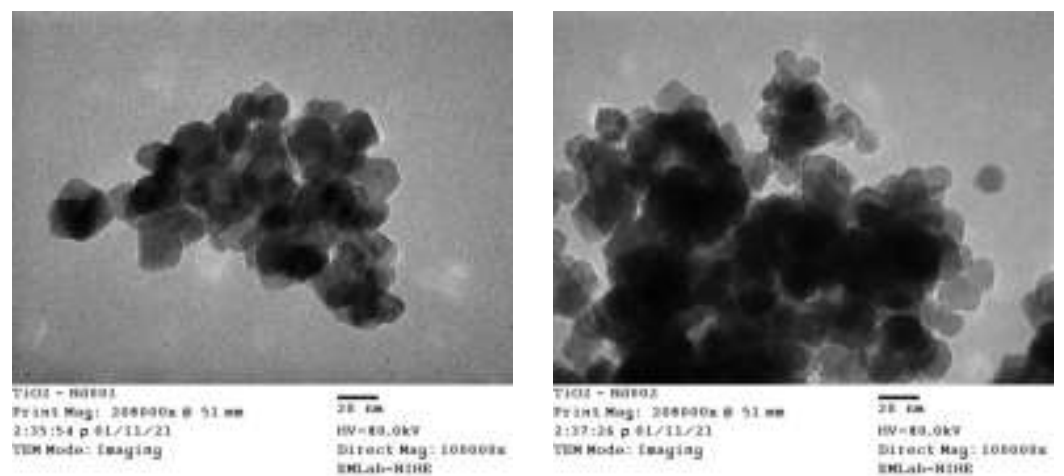

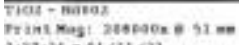

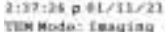

BN- ta. ok:

Ditract Mag: tosoesa
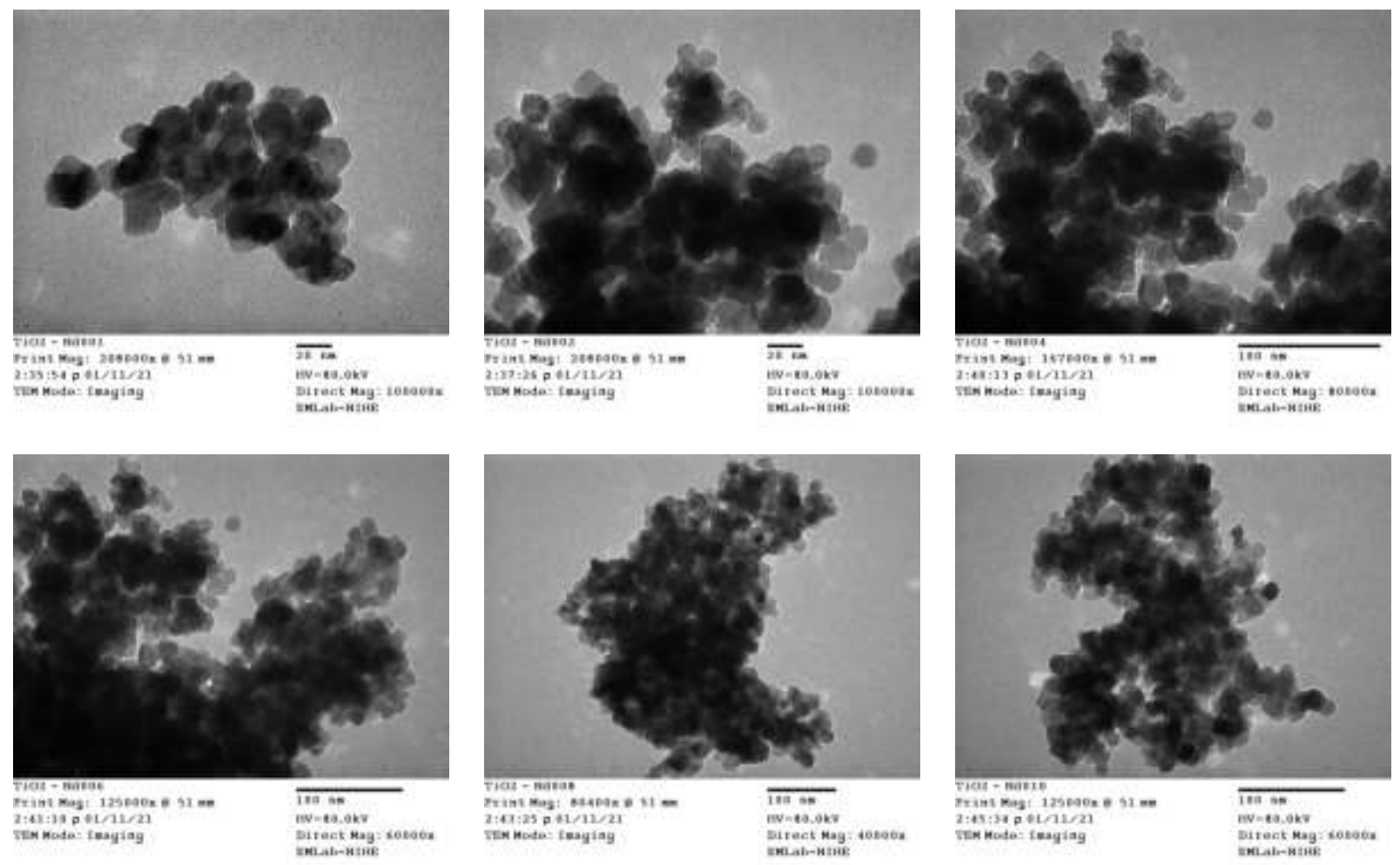

Figure 2. TEM image of $\mathrm{TiO}_{2} / \mathrm{Nd}$ modified nanomaterials with different $\mathrm{Nd}$ content 

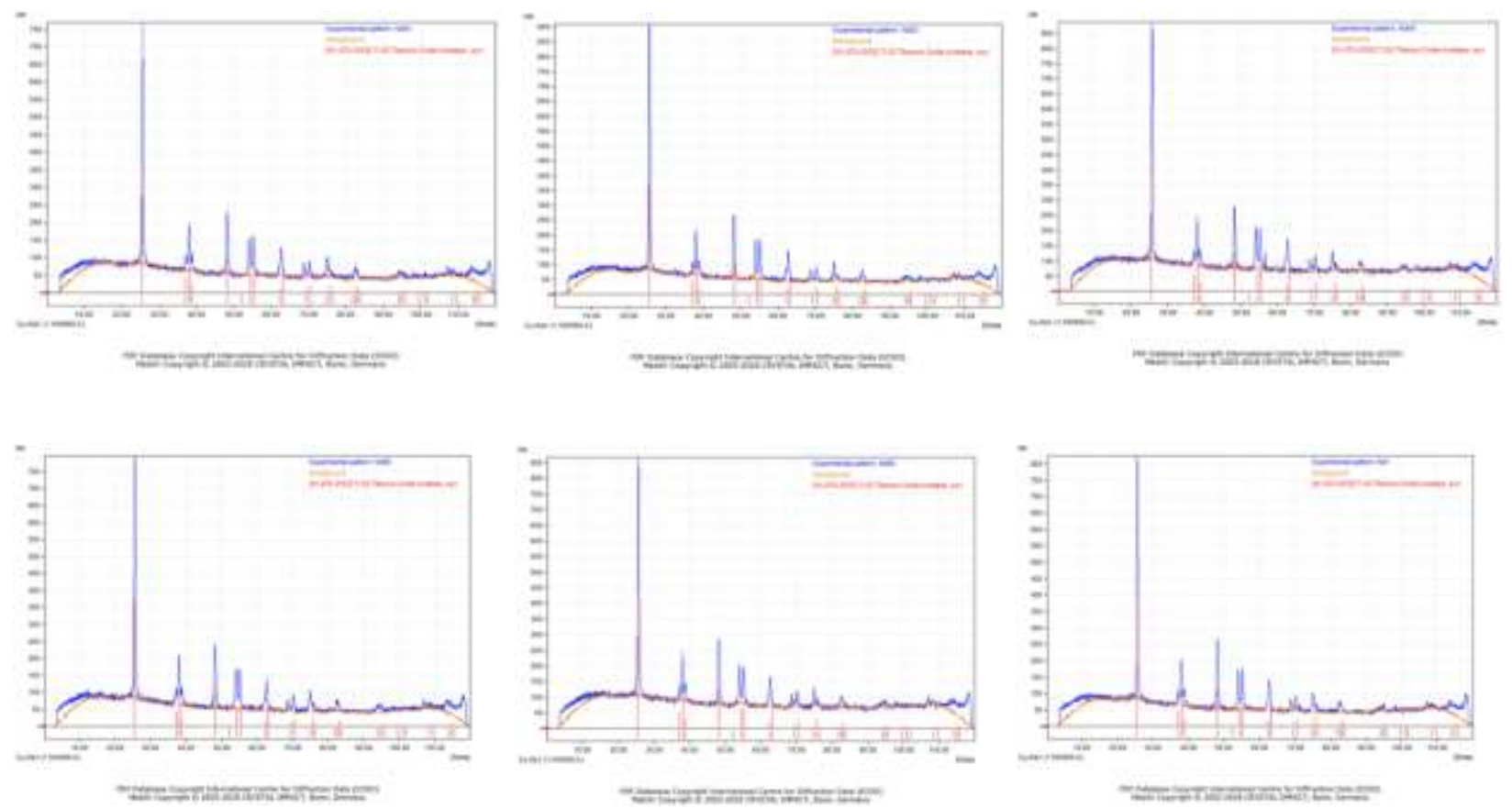

Figure 3. $\mathrm{XRD}$ images of nano $\mathrm{TiO}_{2} / \mathrm{Nd}$ modified materials with different $\mathrm{Nd}$ content 

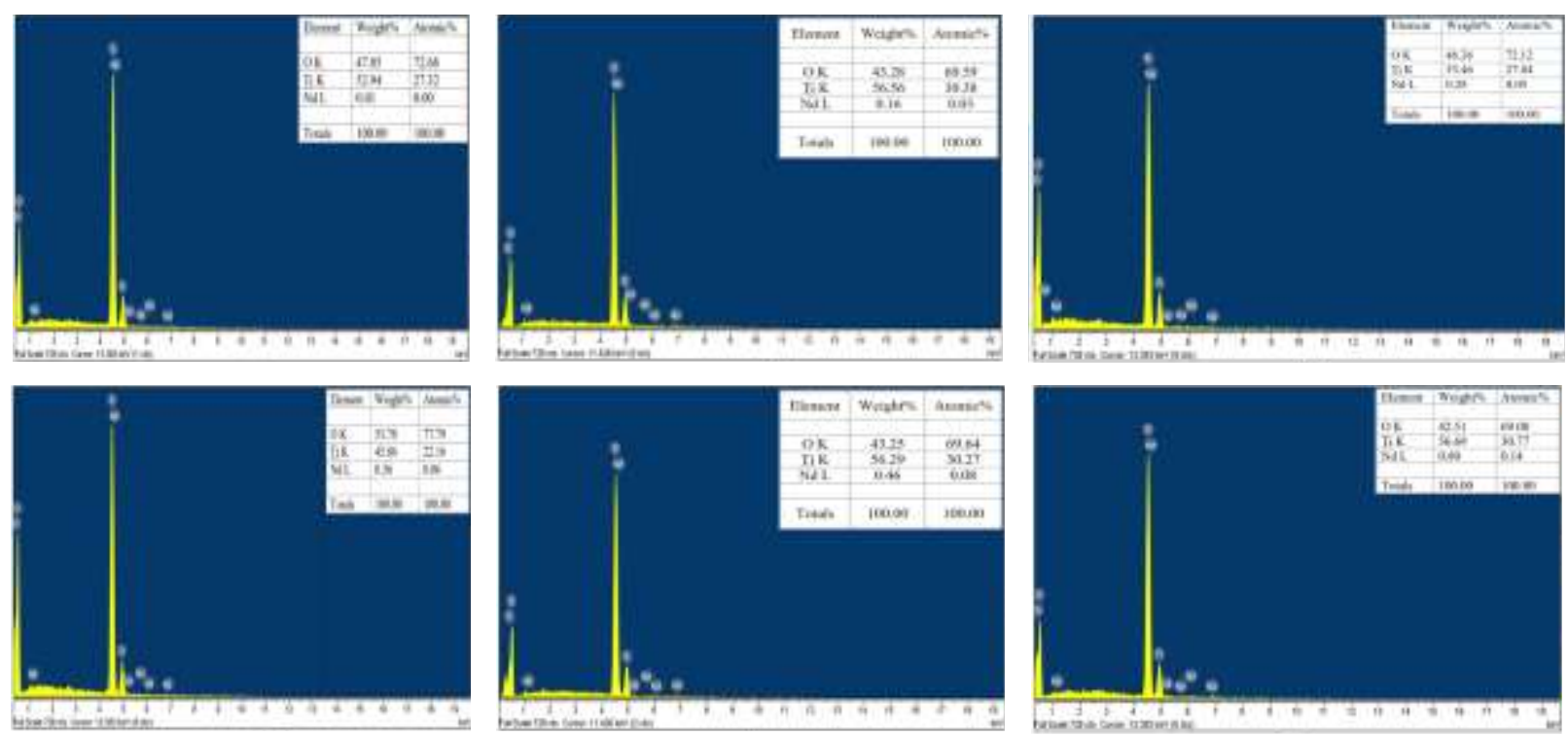

Figure 4. EDX images of $\mathrm{TiO}_{2} / \mathrm{Nd}$ modified nanomaterials with different $\mathrm{Nd}$ contents 

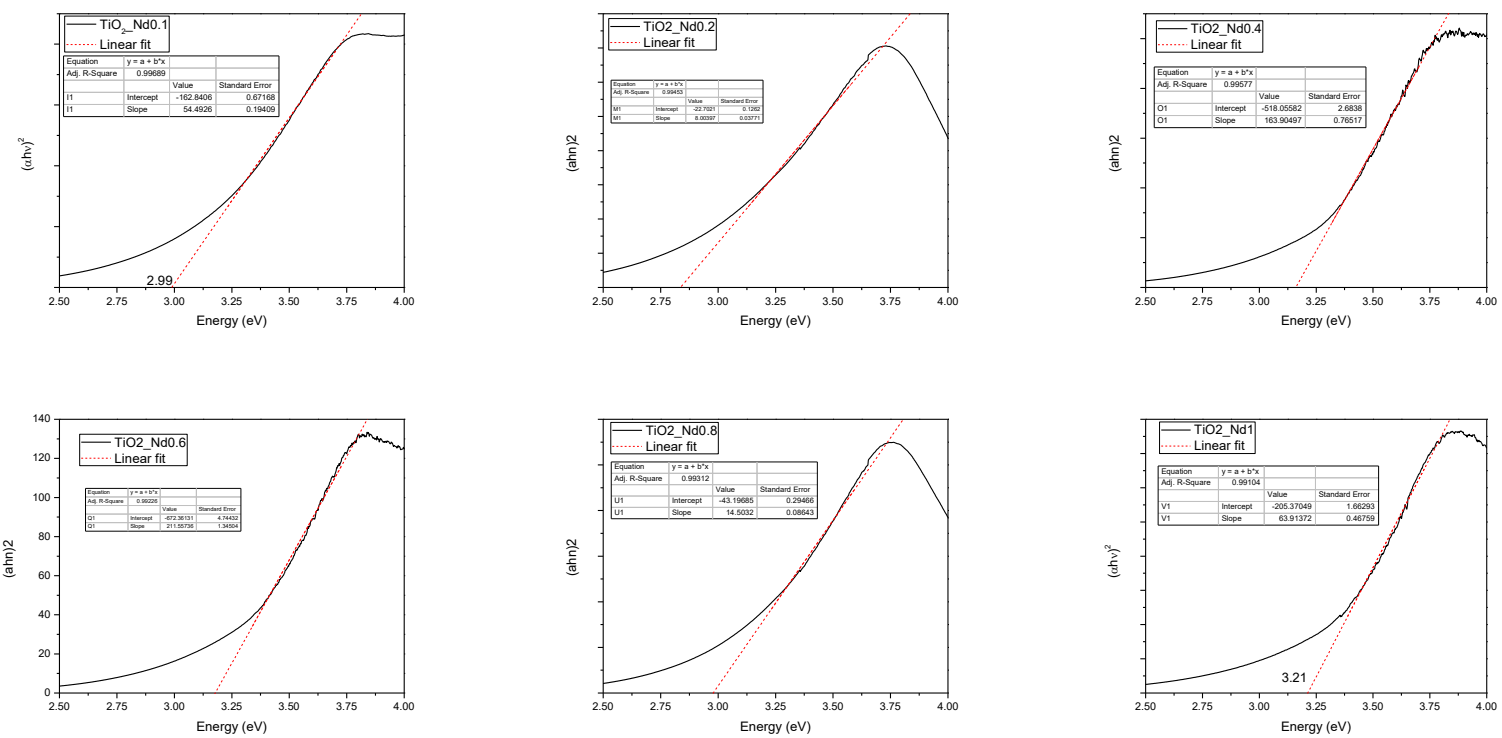

Figure 5. Eg spectrum of $\mathrm{TiO}_{2} / \mathrm{Nd}$ modified nanomaterials with different $\mathrm{Nd}$ contents 


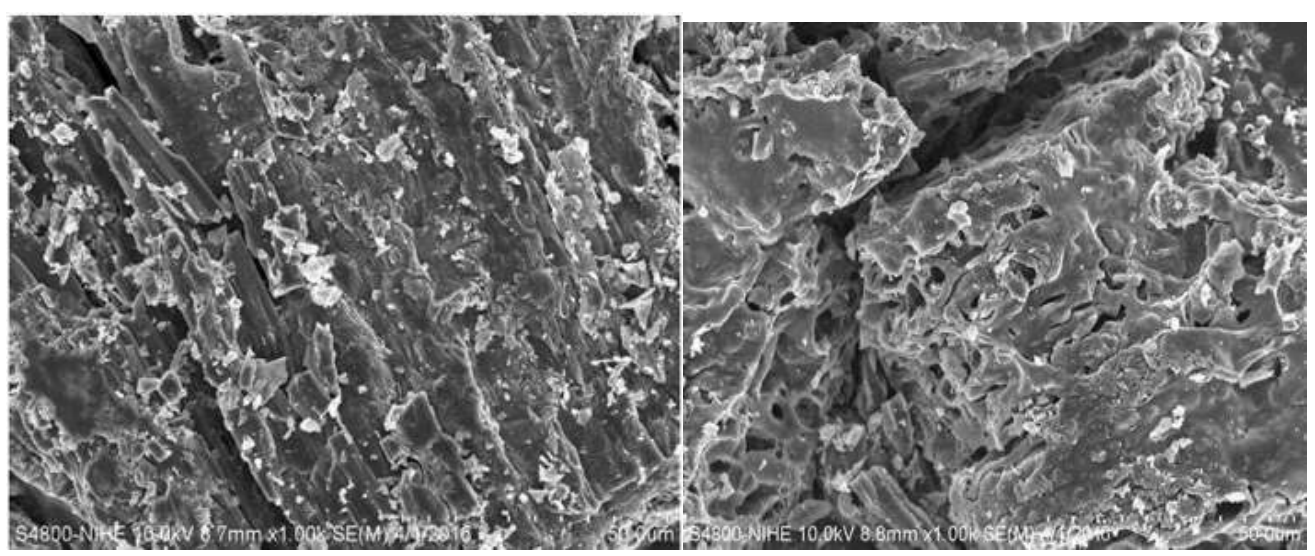

(a)

(b)

Figure 6. SEM images of rice husk ash (a) and nano $\mathrm{TiO}_{2} / \mathrm{Nd} /$ rice husk ash (b) 


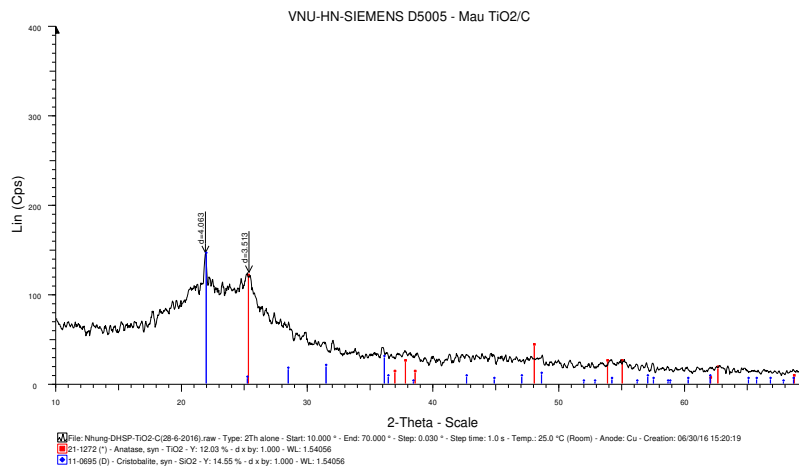

(a)

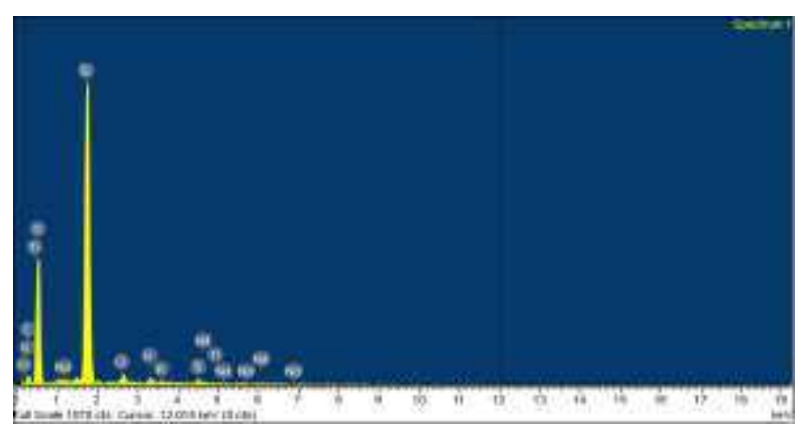

(b)

Figure 7. $\mathrm{XRD}$ (a) and $\mathrm{EDX}$ (b) spectrum of nano $\mathrm{TiO}_{2} / \mathrm{Nd}$ /rice husk ash 


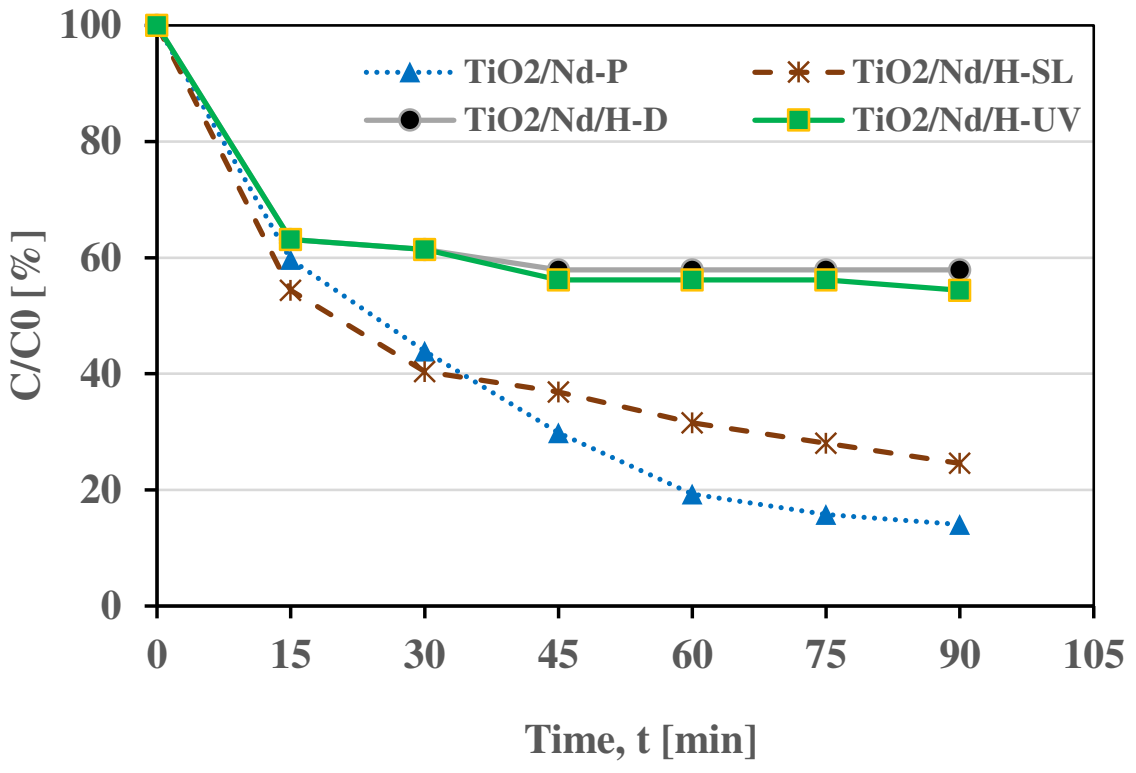

Figure 8. Rifampicin removal efficiency of nano $\mathrm{TiO}_{2} / \mathrm{Nd}$ and $\mathrm{TiO}_{2} / \mathrm{Nd} /$ rice husk ash under different conditions $\left(\mathrm{TiO}_{2} / \mathrm{Nd}-\mathrm{P}\right.$ : nano $\mathrm{TiO} 2 / \mathrm{Nd}$, natural light; $\mathrm{TiO}_{2} / \mathrm{Nd} / \mathrm{H}-\mathrm{SL}$ : $\mathrm{TiO}_{2} / \mathrm{Nd} /$ rice husk ash, natural light; $\mathrm{TiO}_{2} / \mathrm{Nd} / \mathrm{H}-\mathrm{D}: \mathrm{TiO}_{2} / \mathrm{Nd} /$ rice husk ash, dark) 

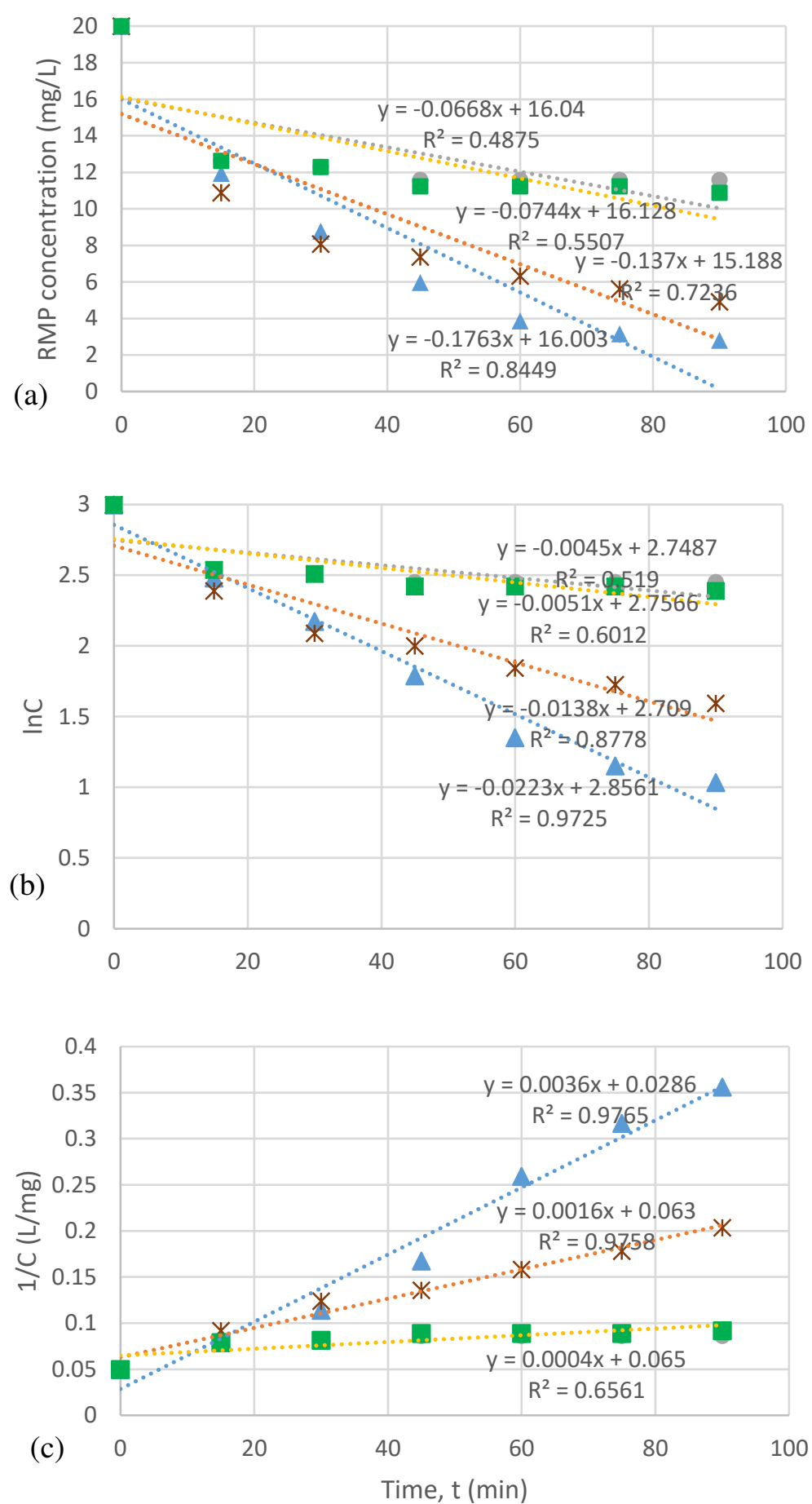

$\triangle \mathrm{TiO} 2 / \mathrm{Nd}-\mathrm{P} \quad \boldsymbol{*} \mathrm{TiO} 2 / \mathrm{Nd} / \mathrm{H}-\mathrm{SL} \quad \mathrm{TiO} 2 / \mathrm{Nd} / \mathrm{H}-\mathrm{D} \quad \mathrm{TiO} 2 / \mathrm{Nd} / \mathrm{H}-\mathrm{UV}$

Figure 9. Concentration of rifampicin remaining versus time according to :zero-order reaction (a), first-order reaction (b) and second-order reaction (c) 


\section{Tables}

Table 1. Composition and rate of chemicals prepared nano $\mathrm{TiO}_{2}$ modified $\mathrm{Nd}$ by the solgel hydrothermal method

\begin{tabular}{cccccc}
\hline Chemical & $\mathrm{NH}_{4} \mathrm{NO}_{3}(1.0 \mathrm{M})$ & $\left(\mathrm{NH}_{2}\right)_{2} \mathrm{CO}(1.0 \mathrm{M})$ & $\mathrm{PVA}(1.0 \mathrm{M})$ & $\mathrm{TiCl}_{4}(0.5 \mathrm{M})$ & $\mathrm{Nd}^{3+}(1.0 \mathrm{~g} / \mathrm{L})$ \\
\hline $\begin{array}{c}\text { Volume } \\
(\mathrm{ml})\end{array}$ & 60 & 450 & 180 & 60 & $0.1-1.0$ \\
\hline
\end{tabular}


Table 2. Lattice parameters, particle size and density of $\mathrm{TiO}_{2} / \mathrm{Nd}$ modified nanomaterials with different $\mathrm{Nd}$ content

\begin{tabular}{|c|c|c|c|c|}
\hline \multirow{2}{*}{$\begin{array}{c}\mathrm{Nd} / \mathrm{TiO}_{2} \text { ratio } \\
(\% \mathrm{w} / \mathrm{w})\end{array}$} & \multirow{2}{*}{ Samples } & \multicolumn{2}{|c|}{ Lattice parameters } & \multirow{2}{*}{$\begin{array}{l}\text { Density, D } \\
\left(\mathrm{g} / \mathrm{cm}^{3}\right)\end{array}$} \\
\hline & & $\mathrm{a}=\mathrm{b}(\AA)$ & c $(\AA)$ & \\
\hline 0.01 & $\mathrm{TiO}_{2}-\mathrm{Nd} 01$ & \multirow{6}{*}{3.770} & \multirow{6}{*}{9.420} & \multirow{6}{*}{3.962} \\
\hline 0.16 & $\mathrm{TiO}_{2}-\mathrm{Nd} 02$ & & & \\
\hline 0.28 & $\mathrm{TiO}_{2}-\mathrm{Nd} 04$ & & & \\
\hline 0.36 & $\mathrm{TiO}_{2}-\mathrm{Nd} 06$ & & & \\
\hline 0.46 & $\mathrm{TiO}_{2}-\mathrm{Nd} 08$ & & & \\
\hline 0.80 & $\mathrm{TiO}_{2}-\mathrm{Nd} 1$ & & & \\
\hline
\end{tabular}


Table 3. Kinetics calculations: reaction rate constant and regression coefficients

\begin{tabular}{|l|l|l|l|l|l|l|}
\hline Materials & \multicolumn{2}{|l|}{ Zero order kinetic } & \multicolumn{2}{l|}{$1^{\text {st }}$ order kinetic } & \multicolumn{2}{l|}{$2^{\text {nd }}$ order kinetic } \\
\cline { 2 - 7 } & $\mathrm{k}$ & $\mathrm{R}^{2}$ & $\mathrm{k}$ & $\mathrm{R}^{2}$ & $\mathrm{k}$ & $\mathrm{R}^{2}$ \\
\hline $\mathrm{TiO}_{2} / \mathrm{Nd}-\mathrm{P}$ & 0.1763 & 0.85 & 0.0223 & 0.97 & 0.0036 & 0.98 \\
\hline $\mathrm{TiO}_{2} / \mathrm{Nd}-\mathrm{SL}$ & 0.137 & 0.72 & 0.0138 & 0.88 & 0.0016 & 0.98 \\
\hline $\mathrm{TiO}_{2} / \mathrm{Nd} / \mathrm{H}-\mathrm{D}$ & 0.0668 & 0.49 & 0.0045 & 0.52 & 0.0004 & 0.66 \\
\hline $\mathrm{TiO}_{2} / \mathrm{Nd} / \mathrm{H}-\mathrm{UV}$ & 0.0744 & 0.55 & 0.0051 & 0.60 & 0.0004 & 0.66 \\
& & & & & & \\
\hline
\end{tabular}

